\title{
Genetic Variation of Black Capped White Eye Zosterops atricapilla (Aves: Zosteropidae) Based on Mitochondrial DNA Cytochrome B Gene
}

\author{
Deby Permana ${ }^{1}$ Jarulis $^{2, *}$ Sipriyadi $^{2}$ Santi Nurul Kamilah ${ }^{2}$ \\ ${ }^{1}$ Undergraduate Student, Department of Biology, Faculty of Mathematics and Natural Sciences, Universitas \\ Bengkulu, Kandang Limun, Bengkulu 38112, Indonesia \\ ${ }^{2}$ Department of Biology, Faculty of Mathematics and Natural Sciences, Universitas Bengkulu, Kandang Limun, \\ Bengkulu 38112, Indonesia \\ *Corresponding Author. Email: jarulis@unib.ac.id
}

\begin{abstract}
The purpose of this research was to explore the genetic variation of Black Capped White eye Zosterops articapilla using the mitochondrial DNA cytochrome $\mathrm{b}$ gene. The blood sample was collected via pectoral vein of bird from Panorama markets, Bengkulu city. DNA genome were isolated and purified from the blood following DNeasy protocol® Blood and Tissue Kit cat no. 69504 (50), based on Qiagen's Spin-Column Protocol procedure. We used polymerase chain reaction machine for amplification DNA template with specific primer (ZCYTBF and ZCYTBR). The results showed that length of cyt b gene sequence ( $n=6$ ) was 725 bp and had 717 bp $(98.89 \%)$ conservative site. The average of intraspecific genetic distance was 0.04 , interspecific 0.063 , and between Indonesian and overseas (outgroup) was 0.138 .
\end{abstract}

Keywords: Cytb, Conservation, illegal trafficking, mtDNA, Zosteropidae

\section{INTRODUCTION}

Indonesia has an area of approximately 1.9 million $\mathrm{km}^{2}$ of land, with a total area of 8 million $\mathrm{km}^{2}$. With this vast area, Indonesia has approximately 47 different ecosystems and is supported by Indonesia's location in the cross-distribution area of biodiversity from the continents of Asia and Australia and is a transitional area of Wallacea which allows Indonesia to have high endemic species and have unique characteristics and also island location, which are far apart resulting in high speciation resulting in high diversity [1].

One family of aves is Zosteropidae which has 12 genera, and the number of species is about 85 individuals, which are spread unevenly throughout the world. Approximately 50 of these species are located in the Indo-Australian region, their status in the IUCN of Eye glass birds is low risk (LC / least concern). However, the poaching and habitat destruction are a concern for the survival of birds. These conditions, being hunted and trafficked, it can endanger the survival of the bird [2].
According to [3], endangered animals have low levels of genetic variation. The effort that can be made to preserve a species from the threat of extinction is to conserve it ex situ or in situ. The molecular approach can be used as a way of genetic conservation where conservation of this type is a step to save genetic resources by using DNA markers. Therefore, knowledge of variations is required at the molecular level using molecular marker analysis and has been useful for conservation efforts using DNA markings [4].

\section{MATERIALS AND METHOD}

\subsection{Sample Collections}

Six individuals of Black Capped White Eye Zosterops atricapilla was collected from Panorama bird market, Bengkulu city (Table 1). Blood was taking out through the pectoral vein $0.5-1 \mathrm{ml}$ using a $1,0 \mathrm{ml}$ syringe. The blood was put into an EDTA bottle for preservation and stored in a freezer with a temperature of $-20 \mathrm{C}$. 


\subsection{DNA Isolation}

Total DNA isolation was carried out using the Dneasy® Blood and Tissue Kit cat no 69504 (50) based on the modified Qiagen Spin-Column Protocol procedure. The quality of the isolated DNA was observed in $1.2 \%$ agarose gel using electrophoresis, then stored in a freezer $-20^{\circ} \mathrm{C}$ before amplification.

Table 1. Sample Data Analyzed and sample from Genbank

\begin{tabular}{|c|c|c|c|}
\hline No & Sample & $\begin{array}{l}\text { Sample code/ } \\
\text { Accession } \\
\text { Number }\end{array}$ & Region \\
\hline 1 & Zosterops atricapilla & ZA1CYTB & Bengkulu \\
\hline 2 & Zosterops atricapilla & ZA2CYTB & Bengkulu \\
\hline 3 & Zosterops atricapilla & ZA3CYTB & Bengkulu \\
\hline 4 & Zosterops atricapilla & ZA4CYTB & Bengkulu \\
\hline 5 & Zosterops atricapilla & ZA5CYTB & Bengkulu \\
\hline 6 & Zosterops atricapilla & ZA6CYTB & Bengkulu \\
\hline 7 & Zosterops atricapilla & JN827239 & $\begin{array}{l}\text { Mainland Asia } \\
\text { and Afrika }\end{array}$ \\
\hline 8 & $\begin{array}{l}\text { Zosterops } \\
\text { erythropleurus }\end{array}$ & $\mathrm{NC} 027942$ & China \\
\hline 9 & $\begin{array}{l}\text { Zosterops } \\
\text { abyssinicus }\end{array}$ & NC032058 & $\begin{array}{l}\text { Southeast } \\
\text { Kenya }\end{array}$ \\
\hline 10 & Zosterops bobonicus & MK529728 & French \\
\hline 11 & Zosterops japonicus & KT601061 & Japan \\
\hline 12 & Zosterops lateralis & $\mathrm{NC029146}$ & Selandia Baru \\
\hline 13 & $\begin{array}{l}\text { Zosterops } \\
\text { poligastrus }\end{array}$ & NC032059 & East Africa \\
\hline 14 & Yuhina diademata & NC029462 & China \\
\hline 15 & Yuhina diademata & KT783535 & China \\
\hline 16 & Yuhina gularis & MK405666 & China \\
\hline 17 & Yuhina nigrimenta & NC040991 & China \\
\hline 18 & Yuhina nigrimenta & MH916608 & China \\
\hline
\end{tabular}

Sample in this study 1-6, and 7-18 sample from the Genbank

\subsection{PCR and Sequencing}

Target DNA replication in cytochrome b gene is carried out through the amplification process using polymerase chain reaction (PCR) techniques. The primer used for Cytochrome $b$ amplification is designed using the primary tree program available online. Sequence of Cytochrome $b$ gene used to design specific primers in this study derived from the complete genome of mitochondrial DNA of the Zosterops erythropleurus type which collected from GenBank (accesion number NC 027942), namely ZCYTBF (5'-GACACCAACCTAGCCTTTGC-3') and ZCYBR (5'- AACTAGCACT GAG GCGGCTA$3 '$ ), and sequencing DNA send to PT. First Base Malaysia.

\subsection{Data Analysis}

The sequenced nucleotide data (forward and reverse) were edited by alignment using the Clustal W program MEGA 6.0 [5]. BIOEDIT software version 7.0.9 [6], is used for editing the Cytochrome $\mathrm{b}$ gene sequences, and visualization of its electrogram and the sequence of its nucleotide bases. The Cytochrome $b$ gene sequences of each individual were aligned with the Cytochrome $b$ genes that were obtained from GenBank through the basic local alignment search tool-nucleotide (BLASTn) to checking the similarity of the samples tested. The genetic distance between individuals was calculated using Kimura 2-Parameter (K2P) method [7]. The phylogeny tree was reconstructed using the K2P Neighbor-Joining (NJ) model with 1000 replications [5]. We use twelve of cytochrome b sequence form GenBank for analysis.

\section{RESULTS AND DISCUSSION}

\subsection{PCR Product}

Visualization results showed the presence of DNA bands in the six blood samples of Zosterops atricapilla (Figure 1). The length of the sequences obtained was different from previous studies. The research of [8] obtained the length of sequences in the Paridae, Remizidae, and Aegithalos families 948 bp. The research of [9] obtained the sequence length of the three Indonesian hornbill species of $849 \mathrm{bp}$, in [10] study using a sample of parrots the sequence length was $791 \mathrm{bp}$. Based on this description, it can be concluded that the length our Cyt b sequence was shorter than in previous studies.

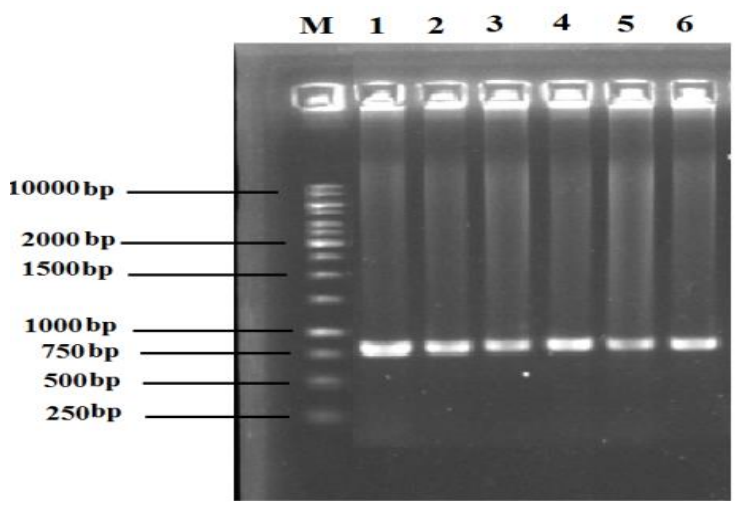

Figure 1. Visualization by gel documentation of $c y t \mathrm{~b}$ in agarose $1.2 \%$. 
Table 2. BLASTn result of the Black Capped White Eye Cyt b gene 725 bp

\begin{tabular}{|c|c|c|c|c|}
\hline \multirow{2}{*}{ Sample } & \multicolumn{3}{|c|}{ BLASTn } & \multirow{2}{*}{ Locality } \\
\hline & Species & Query cover (\%) & Identity (\%) & \\
\hline \multirow[t]{3}{*}{ Zosterops atricapilla } & Z. erythropleurus & 100 & 97,70 & Beijing, China \\
\hline & Z. japonicus & 99 & 96,14 & Japan \\
\hline & Z. atricapilla & 99 & 95,86 & Daratan Asia dan Afrika \\
\hline \multirow[t]{3}{*}{ Zosterops atricapilla } & Z. erythropleurus & 99 & 96,42 & Beijing, China \\
\hline & Z. japonicus & 99 & 95,86 & Jepang \\
\hline & Z. atricapilla & 99 & 95,59 & Mainland Asia dan Africa \\
\hline \multirow[t]{3}{*}{ Zosterops atricapilla } & Z. erythropleurus & 100 & 96,42 & Beijing, China \\
\hline & Z. japonicus & 99 & 95,86 & Japan \\
\hline & Z. atricapilla & 99 & 95,59 & Mainland Asia dan Africa \\
\hline \multirow[t]{3}{*}{ Zosterops atricapilla } & Z. erythropleurus & 100 & 96,56 & Beijing, China \\
\hline & Z. japonicus & 99 & 96,00 & Japan \\
\hline & Z. atricapilla & 99 & 95,72 & Mainland Asia dan Africa \\
\hline \multirow[t]{3}{*}{ Zosterops atricapilla } & Z. erythropleurus & 99 & 96,28 & Beijing, China \\
\hline & Z. japonicus & 99 & 95,59 & Japan \\
\hline & Z. atricapilla & 99 & 95,31 & Mainland Asia dan Africa \\
\hline \multirow[t]{3}{*}{ Zosterops atricapilla } & Z. erythropleurus & 100 & 96,56 & Beijing, China \\
\hline & Z. japonicus & 99 & 96,00 & Japan \\
\hline & Z. atricapilla & 99 & 95,72 & mainland Asia dan Afrika \\
\hline
\end{tabular}

\subsection{Species Identification}

Based on the results of BLASTn, we found that the highest identity of all samples $(n=6)$ was $97.70 \%$ and the lowest identity $95.31 \%$. All the Zosterops spp. species identified in the Genbank data come from outside Indonesia, and there are one species of the same type but different places of collection, namely in the plains of Asia and Africa with the lowest identity value of $95.31 \%$ and the highest $95.72 \%$. These data suggest that our Zosterops atricapilla $\mathrm{Cyt} b$ gene sequence are new data.

\subsection{Nucleotide Variation and Composision}

Variation and composition of nucleotides from intraspecies to the six samples of Zosterops atricapilla by the results of the Cyt $\mathrm{b}$ gene alignment in MEGA 6 application and assisted with Clustal W, has 717 of a conservative site $(98.89 \%), 8$ bp of variable site $(1.10 \%)$, parsimony $4(0.55 \%)$ site, and singleton $4(0.55 \%)$ site. Total sites varied were 12 sites $(1.67 \%)$.

The composition of each type of nucleotide base of the six individuals of Zosterops atricapilla were quite varied (Table 3). The type of nucleotide that has the highest composition in the six species was cytosine with a value of $32.4-32.7 \%$ and the lowest was guanine with a value of $15.4-15.6 \%$, this is by [10] that the composition of guanine has the composition smaller than the cytosine composition. The composition of the nucleotide base pairs of Adenine and Thymine is known to be above GC with AT values ranging from $51.7 \%-52 \%$ and GC from $47.8 \%-48.3 \%$. In the study [9] the composition of AT was higher than GC and in research [10] the composition of AT and GC were $50.7 \%$ and $49.3 \%$ in the genus Lophura (Galliformes) respectively. 
Table 3. Character and Nucleotide Composition of Zosterops atricapilla based on Cyt b Gene with length $725 \mathrm{bp}$.

\begin{tabular}{|c|c|c|c|c|c|c|c|c|}
\hline \multirow[t]{2}{*}{ Species } & \multirow[t]{2}{*}{ Conserved Site } & \multicolumn{3}{|c|}{ Variable Site } & \multirow[b]{2}{*}{$\mathbf{A}$} & \multicolumn{3}{|c|}{$\begin{array}{c}\text { Nucleotide Composision } \\
(\%)\end{array}$} \\
\hline & & $\mathbf{V}$ & $\mathbf{P i}$ & $\mathbf{S}$ & & $\mathbf{T}$ & $\mathbf{G}$ & $\mathbf{C}$ \\
\hline Zosterops atricapilla 1 & \multirow{6}{*}{717} & \multirow{6}{*}{8} & \multirow{6}{*}{4} & \multirow{6}{*}{4} & 27.0 & 25.0 & 15.6 & 32.4 \\
\hline Zosterops atricapilla2 & & & & & 27.2 & 25.0 & 15.4 & 32.4 \\
\hline Zosterops atricapilla 3 & & & & & 26.9 & 24.8 & 15.6 & 32.7 \\
\hline Zosterops atricapilla4 & & & & & 26.9 & 25.0 & 15.6 & 32.6 \\
\hline Zosterops atricapilla5 & & & & & 27.0 & 24.8 & 15.6 & 32.6 \\
\hline Zosterops atricapilla6 & & & & & 27.2 & 25.0 & 15.4 & 32.4 \\
\hline
\end{tabular}

\subsection{Nucleotide Polymorphism}

The results of the alignment of the Cyt b gene sequence from the six individuals of Zosterops atricapilla showed a specific nucleotide or single nucleotide polymorphism (SNP) (Table 4). A total of 8 different nucleotide sites were found located between sites number 7 and 725 . Zosterops atricapilla 5 was the individual that has the most specific nucleotides (five sites) compared to other. In the research of [9], a total of 17 different nucleotide sites were found, which are between sites number 41 and 671. Each species has a different length of nucleotide sites, in the research of [9], the types of hornbills studied had different nucleotide base sites, each type of species had slight differences in intraspecies in their specific nucleotide sequences [11]. Cyt b gene nucleotides can be used as genetic markers in explaining genetic diversity in flocks of chickens [12].

Table 4 SNP of Zosterops atricapilla based on Cyt B gene with length $725 \mathrm{bp}$

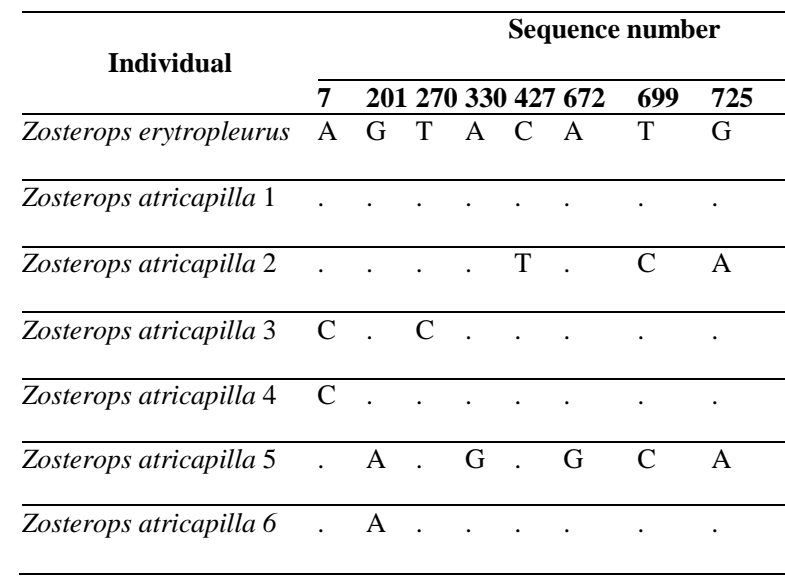

\subsection{Genetic Distance}

Genetic distances were calculated using the Kimura 2-Parameter method. Then the minimum value for group one is $0.01 \%$ and the highest $1 \%$. Genetic distance in the same family has a minimum value of $3.4 \%$ and maximum $8.5 \%$. A minimum value of genetic distance in the same genus was $1.3 \%$ and a maximum $15.4 \%$. This genetic distance has the same tendency as previous studies, in the study of [8] used the Paridae and Remizidae families found the mean distance between species was 0.081 and 0.007 , the mean distance between the genus was 0.077 and 0.005 , and the distance between taxa was 0.115 and 0.009. In [10] study using parrots, the minimum distance ranged between $1.0 \%$ and $22.8 \%$, and in the research of [9] the minimum genetic distance in the Indonesian hornbill species was obtained $4.80 \%$, the maximum genetic distance is $5.70 \%$, and the mean distance for group one is $0.04(4 \%)$ in group two $6.3 \%$ and $13.8 \%$ in group three. in the research of [10] the genetic distance of the three Lophura individuals is $0.13 \%$.

In GenBank, there are the same species which are then used as a reference to see the genetic distance of the two species (Figure 2). Zosterops atricapilla species with GenBank accession number JN827239, samples were taken from mainland Asia to Africa, while the sample used in the study was Zosterops atricapilla from Indonesia, and it can be seen that the genetic distance of the two samples was quite far apart but still in the same cluster. Factors affecting the genetic distance of a species are low, namely, the number of samples analyzed is small, the genetic diversity of birds taken as a small sample due to their small population, and the birds are endemic [13]. 
Table 5. Genetic distence average of intraspecies and interspecies of Z. atricapilla

\begin{tabular}{lccl}
\hline Genetic Distance & Min. & Max. & Average \\
\hline Interspesies Z. Atricapilla & 0,001 & 0,010 & 0,004 \\
\hline $\begin{array}{l}\text { Z. atricapilla vs interspecies } \\
\text { Zosterops }\end{array}$ & 0,034 & 0,085 & 0,060 \\
\hline Z. atricapilla vs Yuhina & 0,013 & 0,154 & 0,132 \\
\hline
\end{tabular}

The genetic distance is expressed close if the value ranges from $0.010-0.099 \%$, expressed moderately when ranged from $0.100-0.990 \%$ and is expressed far in the value range of $1-2 \%$, two individuals have genetic closeness if the resulting genetic distance value is not more than $0.1 \%$ [14].

Phylogeny analysis usually used to determine how the species was passed down during evolution. In the phylogenetic tree the rate of evolution of a species is demonstrated by horizontal lines and vertical lines on the phylogenetic tree indicating the genetic distance between species. Phylogenetic analysis can be used to determine the proximity and genetic relationship between one species and another [15], phylogenetic analysis using 18 samples, of which 6 main samples and 5 samples are based on genus, 5 samples by family and 1 sample as a reference and 1 sample of the same type of different origin all taken in GenBank. The result of phylogenic tree reconstruction was taken using the Neighbor Joining model with 1000 bostrap reps (Figure 2).

\section{CONCLUSION}

Based on the results of research on Genetic Variations in Zosterops atricapilla from Bengkulu, it proves that from the six samples of Zosterops atricapilla with interspecific variations, genetic distance, samplified using range e.g: 0.1\%-1.0\%, genetic distance in the same family samplified using range $3.4 \%-8.5 \%$, genetic distance in the same genus with a minimum value of $1.3 \%$ and maximum $15.4 \%$. The mean distance for group one was $0.4 \%$, in group two was $6.0 \%$ and in group three was $13.2 \%$.

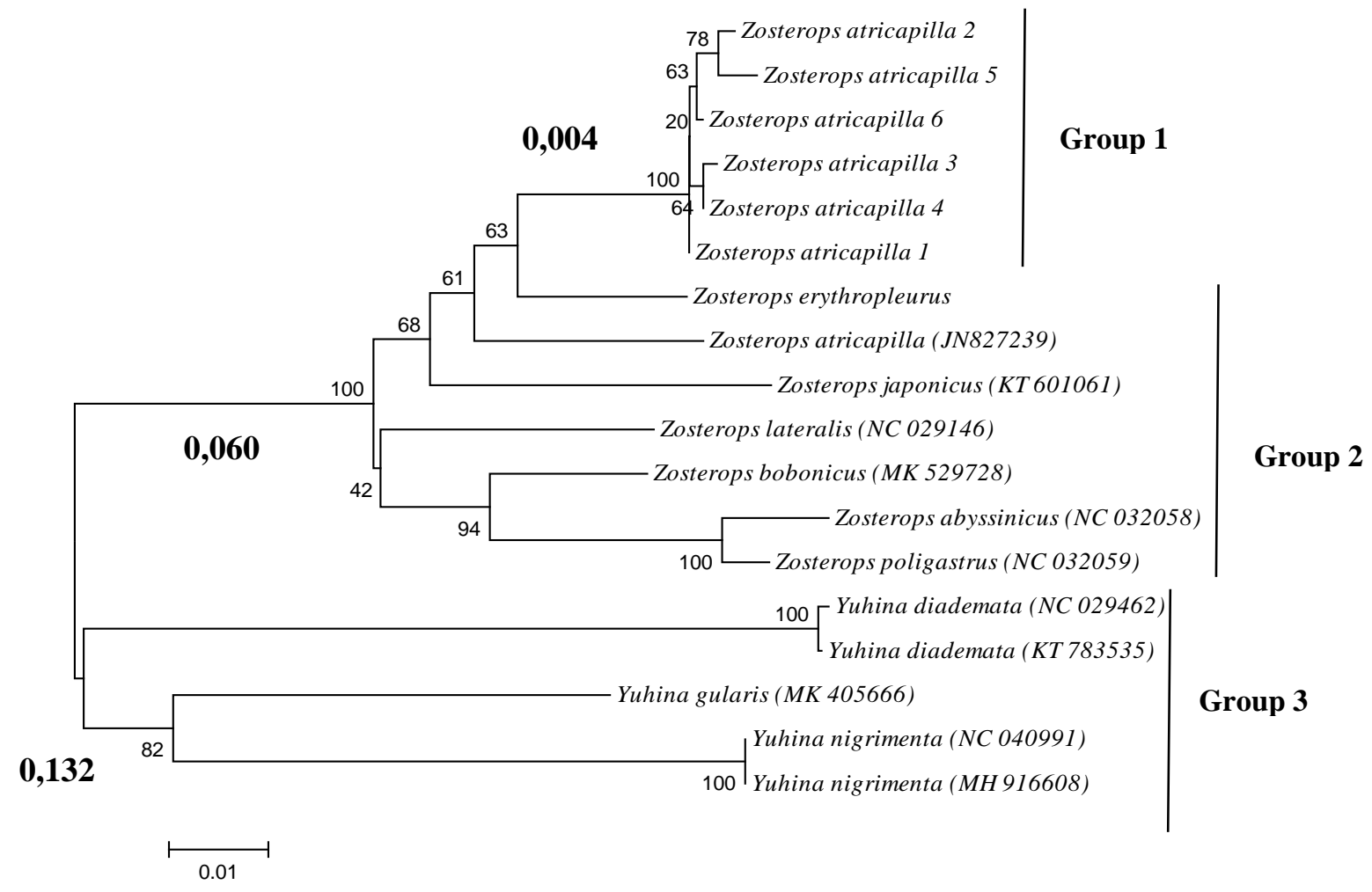

Figure 2. PhylogeneticTree of Neighbor Joining 6 individual Zosterops atricapilla construction with K2P modeling bootstrap 1000x basis on Cyt $\mathrm{b}$ gene mtDNA (725bp) . 


\section{REFERENCES}

[1] W. Novarino, H. Kobayashi, A. Salsabila, Jarulis, N. Janra, Panduan lapangan pencincinan burung di Sumatera (Edisi Pert), Padang, Perpus takaan Nasional, 2008. [In Bahasa Indonesia]

[2] IUCN, Zosterops atricapilla, 8235, 2016.

[3] S.L. Ardern, D.M. Lambert, Is the Black Robin in genetic peril? Molecular Ecology 6(1) (1997) 21-28.

https://doi.org/10.1046/j.1365294X.1997.00147.

[4] J.B. Whittier, D.M. Leslie, R.A. van Den Bussche, Genetic variation among Subspecies of least tern (Sternaantillarum): Implications for Conservation, Water birds 29(2) (2006) 176184.

https://doi.org/10.1675/15244695(2006)29[176: gvasol]2.0.co;2.

[5] K. Tamura, G. Stecher, D. Peterson, A. Filipski, S. Kumar, MEGA 6: Molecular Evolutionary Genetics Analysis version 6.0. Molecular Biology and Evolution 1-5 (2013). DOI: https://doi.org/10.1093/molbev/mst197. [In Bahasa Indonesia]

[6] T.A. Hall, BioEdit: a user-friendly biological sequence alignment editor and analysis program for Windows 95/98NT, Nucleic Acids Symposium Series 41 (1999) 95-98.

[7] M.A. Kimura, Simple method for estimating evolutionary rates of base substitutions through comparative studies of nucleotide sequences, Journal of Molecular Evolution, 16 (1980) 111120.

[8] C. Dai, K. Chen, R. Zhang, X. Yang, Z. Yin, H. Tian, F. Lei. Molecular phylogenetic analysis among species of Paridae, Remizidae and Aegithalos based on mtDNA sequences of COI and cyt b, Chinese Birds 1(2), (2010) 112-123. DOI: https://doi.org/10.5122/cbirds.2010.0003.

[9] Jarulis, D.D. Solihin, A. Mardiastuti, L.B. Prasetyo, Variasi interspesifik Julang (Aves:Bucerotidae) Indonesia berdasarkan gen cytochrome B DNA mitokondria, Jurnal IlmuIlmu Hayati 18 (2018) (99-108). [In Bahasa Indonesia]

[10] D. Astuti, M. Irham, H. Ashari, Variasi nukleotida gen COI pada Burung Sempidan (genus Lophura) [(nucleotide variations of COI gene on Gallopheasants Bird (genus Lophura)],
Jurnal Biologi Indonesia 14(1) (2018) 103-108. [In Bahasa Indonesia]

[11] J. Waugh, DNA barcoding in animal species: Progress, potential and pitfalls, BioEssays 29(2) (2007) 188-197. https://doi.org/10.1002/bies.20529.

[12] X.J. Shen, S. Ito, M. Mizutani, Y. Yamamoto, Phylogenetic analysis in chicken breeds inferred from complete cytochrome $b$ gene information, Biochemical Genetics 40(3-4) (2002) 129-141. https://doi.org/10.1023/A:1015165506752.

[13] E. Furlan, J. Stoklosa, J. Griffiths, N. Gust, R. Ellis, R.M. Huggins, A.R. Weeks, Small population size and extremely low levels of genetic diversity in island populations of the platypus, Ornithorhynchus anatinus, Ecology and Evolution 2(4) (2012) 844-857. https://doi.org/10.1002/ece3.195

[14] Y. Yuliani, A. Yuniaty, A.H. Susanto, Variasi sekuens DNA yang diamplifikasi menggunakan primer atpB-rbcL pada beberapa kultivar kacang tanah, Scripta Biological 4(1) (2017) 11. https://doi.org/10.20884/1.sb.2017.4.1.377. [In Bahasa Indonesia]

[15] R. Nielsen, Z. Yang, Likelihood models for detecting positively selected amino acid sites and applications to the HIV-1 envelope gene, Jurnal Biologi 936 (1994) (1998) 929-936. 